\title{
Fall Forage Biomass and Nitrogen Composition of Winter Wheat Populations Selected from Grain-Only and Dual-Purpose Environments
}

\author{
Charles T. MacKown* and Brett F. Carver
}

\begin{abstract}
Winter wheat (Triticum aestivum L.) is the foundation of many agricultural enterprises in the southern Great Plains and is grown primarily as either a grain-only (GO) or a dual-purpose (DP, grazing plus grain) crop. Traditionally, cultivars are developed in GO systems. Because of genotype $\times$ system interactions, the DP environment may compromise gains in grain yield accrued in GO-developed cultivars. Forage traits for 24 sets of populations (each with unique pedigree) were used to test benefits of tailoring breeding programs for DP wheat. Each set came from the same $F_{2}$ source and contained a base (B) $F_{3}$ bulk population and $F_{5}$ bulk populations mass selected from the $F_{2}$ within either a GO or DP system. Forage biomass and forage total $\mathrm{N}$ and nitrate were measured at the start of fall grazing. Nearly always, the effect of selection environment was consistent across genetic backgrounds. Effect of selection environment on forage biomass of each nursery was significant at $P=0.09$ and $P=0.07$. In 2001, DP-derived populations produced about $5 \%$ less than GO-derived populations; in 2002, the selection effect was not significant $(P=0.38$ and 0.30 ). Selection environment had a significant effect on forage total $\mathbf{N}$, but not nitrate levels. Total $\mathbf{N}$ in DP selections was slightly greater $(2.5 \%, P<0.05)$ than those from $B$ and $G O$ selections. Forage nitrate was affected by genetic background; mean nitrate- $N$ among the 24 backgrounds ranged from 1.3 to $3.1 \mathrm{mg} \mathrm{g}^{-1}$ in 2001 and 0.4 to $1.3 \mathrm{mg} \mathrm{g}^{-1}$ in 2002. Selection in the DP system appears to offer equal or slightly less fall forage biomass without greatly changing forage total $\mathbf{N}$ and nitrate concentrations.
\end{abstract}

$\mathrm{H}$ ARD WINTER WHEAT grown in Oklahoma and the surrounding areas of the Texas Panhandle, southern Kansas, eastern New Mexico, and southeastern Colorado is managed as GO, grazing-only, grazing plus grain (DP), and as a hay or silage crop. Wheat pastures in the southern Great Plains have a pivotal role in the U.S. beef (Bos taurus L.) industry by providing the link for millions of fall stocker calves received annually that pass from more than 500000 farms across the southern USA to feedlots located in the Great Plains. Because grasslands in the southern Great Plains are dominated by warm-season species, the predominate source of cool-season forage is wheat. Consequently, as much as $80 \%$ of the total wheat acreage in the southern Great Plains is grazed (Pinchack et al., 1996). Typically in Oklahoma, about $40 \%$ of the wheat acreage is grown as a DP crop (Hossain et al., 2004). Wheat producers choosing a DP management system have greater flexibility and additional economic advantages compared

C.T. MacKown, USDA-ARS, Grazinglands Research Lab., 7207 W. Cheyenne St., El Reno, OK 73036; B.F. Carver, Dep. of Plant and Soil Sciences, 368 Ag Hall, Oklahoma State Univ., Stillwater, OK 74078. Received 3 Mar. 2004. *Corresponding author (cmackown@ grl.ars.usda.gov).

Published in Crop Sci. 45:322-328 (2005)

(C) Crop Science Society of America

677 S. Segoe Rd., Madison, WI 53711 USA with those choosing to grow wheat as a forage-only or GO crop (Redmon et al., 1995), but they need to follow a recommended set of management practices to optimize returns.

When market conditions favor the forage value more than the grain value of wheat intended for DP, the crop should be planted earlier (Hossain et al., 2003) and seeded more densely (Epplin et al., 2000) than GO wheat. To assure early fall growth, fertilizer $\mathrm{N}$ needed to achieve a desired grain yield plus additional $\mathrm{N}$ to account for $\mathrm{N}$ removal in consumed forage is usually applied at planting (Krenzer, 1994; Zhang et al., 1998). These DP management practices may add certain risks. An early planting date in the southern Great Plains favors the incidence and severity of soil-borne and insect transmitted disease (Hammon et al., 1996; Hunger et al., 2002; Piccinni et al., 2001) and insect herbivory (Royer et al., 1997) and can reduce grain yields by variable amounts depending on the year or cultivar (Epplin and Peeper, 1998; Carver et al., 2001). These disease risks are necessary, however, when the goal is to produce a sufficient base of fall forage that is well anchored in the soil. Another potential risk arises from additional $\mathrm{N}$ fertilizer applied in the fall. The extra $\mathrm{N}$ can increase the nitrate levels in wheat forage (Raun and Westerman, 1991; MacKown and Weik, 2004), thereby increasing potential health risks affecting performance of young grazing ruminants (Strickland et al., 1995; Undersander et al., 1999).

Wheat cultivars used for DP are typically developed by wheat breeders that make selections based on performance in GO production systems rather than DP systems. Because of genotype $\times$ environment interactions (Krenzer et al., 1992) and genotype $\times$ production system interactions, cultivar development based solely on selection in a GO production system may compromise gains in genetic improvement of desirable traits for wheat used in DP production (Khalil et al., 2002). Furthermore, forage and grain yields of small-grain cereals are uncorrelated (Ud-Din et al., 1993) or only poorly correlated (Atkins et al., 1969), which underscores the need to consider both forage and grain traits of wheat intended for use as a DP crop. Because the evaluation and selection of wheat genotypes in a DP system has the added complexity and expense of using livestock, knowledge of the benefits of using a DP production system to select genotypes intended for DP is essential. The objective of our research was to compare fall forage traits of bulk populations of wheat crosses selected from GO and DP systems to evaluate the benefits of tailoring a wheat breeding program for DP wheat. Traits targeted included shoot biomass, total $\mathrm{N}$, and nitrate concentration at the onset of fall grazing. 
Table 1. Genetic background of winter wheat bulk subpopulations used to evaluate fall forage traits in two nurseries (Nursery 1 and Nursery 2) in 2001 and 2002.

\begin{tabular}{|c|c|c|}
\hline Set & Nursery 1 & Nursery 2 \\
\hline $\mathbf{1}$ & $2180 / / \mathrm{Crr}^{*} 2 / \mathrm{Cty} \mathrm{A}-/ 3 /$ Ogallala & Oro Blanco/Custer \\
\hline 2 & Tkw//Karl 92*2/CtyA-/3/Hickok & Betty/TAM 302 \\
\hline 3 & Platte//KS137-337/Wakefield & OK9691E8/OK97G605 \\
\hline 4 & $\begin{array}{l}\text { Plainsman V/OK79256 seln// } \\
\text { FL302/3/Jagger }\end{array}$ & Oro Blanco/KS85W663-11-6 \\
\hline 5 & Custer/FL302//TAM 302 & KS94WGRC32/OK93P735 \\
\hline 6 & KS92P0363-134/FL302//Ogallala & KS94WGRC33/TAM 302 \\
\hline 7 & Jagger*2/FL302 & OK93P735/OK94P512 \\
\hline 8 & 2137/SW76-117C-4 & OK91P648/2137 \\
\hline 9 & OK95G702/OK91P648 & OK93617/OK94519 \\
\hline 10 & OK95G703/2137 & OK93Р634/TAM 302 \\
\hline 11 & OK95G703/OK92403 & N44/OK94P455 \\
\hline 12 & OK95G704/OK91P648 & 2174 Bulk 4 \\
\hline
\end{tabular}

\section{MATERIALS AND METHODS}

\section{Development of Experimental Materials}

Released and experimental genotypes of winter wheat were hybridized in single-cross and three-way-cross combinations to form 23 populations (Table 1). These combinations constituted a representative sample of crosses routinely made in the winter wheat cultivar development program at Oklahoma State University. From the $\mathrm{F}_{1}$ generation grown in the greenhouse, each $\mathrm{F}_{2}$ seedlot was divided and planted in field plots assigned to GO and DP systems at the Wheat Pasture Center near Marshall, OK, in the fall of 1997. Seed harvested from plots in each system was planted in the same respective system in two subsequent generations (Fig. 1), ending with the $F_{4}$ generation harvested in 1999. The term subpopulation will be used to identify a population advanced in one of the two selection environments (GO or DP management system). Generation advance was achieved by harvesting each subpopulation in bulk. No artificial selection was imposed beyond that emanating from environmental conditions inherent to each system. In addition to the system-derived pairs of subpopulations, a base subpopulation was produced by growing the original $F_{2}$ generation in a seed-increase nursery at Stillwater, $\mathrm{OK}, 56 \mathrm{~km}$ east of the Wheat Pasture Center. This singlegeneration increase offered a reasonable compromise for producing sufficient seed for field testing and maintaining genetic variability present in the original $F_{2}$ population, while restricting natural selection in a field environment to one year.

An additional set of three subpopulations was generated, for a total of 24 sets, by treating a foundation-seed source of the hard red winter wheat cultivar 2174 in the same way as the hybridized populations. Though considered to be an $\mathrm{F}_{3}$ derived highly homozygous line, 2174's appearance as a heterogeneous line lent itself to treatment as a bulk population. Hence, 24 sets of three subpopulations comprised the experimental materials used in this study. System-derived subpopulations were evaluated as $\mathrm{F}_{5}$ bulks, whereas the base subpopulations were evaluated as $\mathrm{F}_{3}$ bulks.

Agronomic practices followed during the generation-advance stages $\left(\mathrm{F}_{2}-\mathrm{F}_{4}\right)$ were consistent with those used by wheat producers in the southern Great Plains (Krenzer, 1994). The corresponding cropping seasons were 1997-1998, 1998-1999, and 1999-2000. The two management systems were established in the same 9- to 10-ha pasture, separated by an electrical fence to contain grazing cattle in the DP area. Stocker cattle grazed the wheat pasture as part of stocking rate or supplementation studies conducted at the Center, with a target stocking rate of 2 steers $\mathrm{ha}^{-1}$. Stocking rate was adjusted within the grazing season according to forage availability. Grazing commenced during late October to late November. Grazing termination

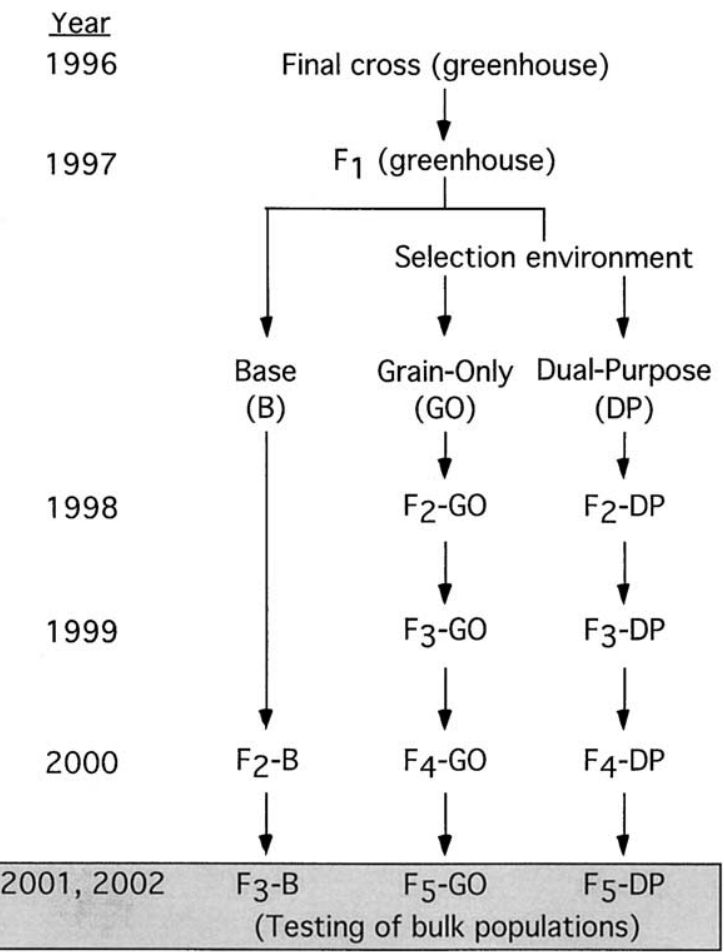

Fig. 1. Generation sequence of base $(B)$ and selected (grain-only, GO; dual-purpose, DP) bulk subpopulations of winter wheat used for testing in a DP system.

occurred in late February to early March, as determined by the appearance of hollow stems in nongrazed plants of an early maturing cultivar planted on the same day as the DP plots. Additional details regarding pasture management, forage availability, and cattle performance were provided by Khalil et al. (2002) for the 1997-1998 and 1998-1999 cropping seasons, and are representative of the 1999-2000 season.

Plots representing the DP system were planted 3 Sept. 1997, 28 Sept. 1998, and 22 Sept. 1999, with a seeding rate of $77 \mathrm{~kg}$ $\mathrm{ha}^{-1}$. Plots in the GO system were planted about 3 to $5 \mathrm{wk}$ later: 17 Oct. 1997, 16 Oct. 1998, and 29 Oct. 1999, with a seeding rate of $58 \mathrm{~kg} \mathrm{ha}^{-1}$. No fungicides were applied to control diseases, which primarily consisted of leaf rust caused by Puccinia triticina Eriks. in both systems. Symptoms of barley yellow dwarf were noticeable only in the early planted DP system. The soil was a fine, mixed, superactive, thermic Udertic Paleustoll (Kirkland silt loam). Actual applied N, in the form of anhydrous ammonia, was adjusted for residual mineral nitrogen in the top $60 \mathrm{~cm}$ of soil. Nitrogen was applied across the entire pasture in amounts considered adequate to meet a grain yield goal of $3000 \mathrm{~kg} \mathrm{ha}^{-1}$ and a dry forage yield of $3500 \mathrm{~kg} \mathrm{ha}^{-1}$. Soil phosphorus and potassium were adequate for these targets, but the pasture was limed with $2500 \mathrm{~kg} \mathrm{ha}^{-1}$ effective calcium carbonate equivalent in July 1998 to correct soil $\mathrm{pH}$ that had declined to $<5.0$.

All plots were harvested for grain on the same day, typically in early June. Each plot was $3 \mathrm{~m}$ long with five rows spaced $23 \mathrm{~cm}$ apart. The three middle rows were harvested with a rice binder to collect seed to advance to the next generation.

\section{Field Testing of Experimental Materials}

The 24 triplicate sets of subpopulations were arbitrarily divided into two nurseries of 12 sets each (Nursery 1, Nursery 2) to accommodate replicated field testing. Using a split-plot design with three complete blocks, the 12 sets were assigned 
Table 2. Significance values from the ANOVA for biomass, total N, and nitrate-N in fall forage samples collected from two nurseries (Nursery 1 and Nursery 2) at the onset of grazing in 2001 and 2002.

\begin{tabular}{|c|c|c|c|c|c|}
\hline \multirow[b]{2}{*}{ Trait } & \multirow[b]{2}{*}{ Effect $\dagger$} & \multicolumn{2}{|c|}{2001} & \multicolumn{2}{|c|}{2002} \\
\hline & & Nursery 1 & Nursery 2 & Nursery 1 & Nursery 2 \\
\hline \multirow{3}{*}{ Biomass, $\mathrm{kg} \mathrm{ha}^{-1}$} & G & 024 & 0040 & 0244 & 0136 \\
\hline & S & 0.093 & $\begin{array}{l}0.068 \\
0.068\end{array}$ & $\begin{array}{l}0.244 \\
0.379\end{array}$ & $\begin{array}{l}0.150 \\
0.302\end{array}$ \\
\hline & $\mathbf{G} \times \mathbf{S}$ & 0.423 & 0.246 & 0.101 & 0.544 \\
\hline \multirow{3}{*}{ Total $\mathbf{N}, \mathbf{m g ~ g}^{-1}$} & G & 0.475 & 0.067 & 0.036 & 0.009 \\
\hline & $\mathbf{S}$ & $<\mathbf{0 . 0 0 1}$ & $<\mathbf{0 . 0 0 1}$ & 0.004 & $<0.001$ \\
\hline & $\mathbf{G} \times \mathbf{S}$ & 0.083 & 0.004 & 0.525 & 0.911 \\
\hline \multirow{3}{*}{ Nitrate-N, $\mu \mathbf{g ~}^{-1}$} & G & $<\mathbf{0 . 0 0 1}$ & 0.021 & 0.021 & 0.002 \\
\hline & $\mathbf{S}$ & 0.909 & 0.296 & 0.296 & 0.419 \\
\hline & $\mathbf{G} \times \mathbf{S}$ & 0.340 & 0.122 & 0.122 & 0.320 \\
\hline
\end{tabular}

$\dagger \mathbf{G}=$ genetic background; $\mathbf{S}=$ selection environment.

to main plots, while the subpopulations within sets were assigned to split-plots. Because each set represented a unique cross, they are hereafter referred to as genetic backgrounds. Three commonly grown hard red winter wheat cultivars with different juvenile growth habits were included as checks. These included Custer (semiprostrate), Jagger (semierect to erect), and 2174 (erect). To maintain balance of field design, each check was assigned to a set of three split-plots and randomized along with the 12 sets of experimental genetic backgrounds in each Nursery, though differences among them were considered strictly environmental.

The two nurseries were maintained as separate but contiguous experiments in the field. Experiments were established in the 2001-2002 and 2002-2003 cropping seasons at the Wheat Pasture Center near Marshall, OK, as described above. Plots were established in a DP management system in the same 9- to 10-ha pasture in which the materials were derived. Dualpurpose management practices in this population testing phase were similar to those described for population derivation, except that planting dates were 10 Sept. 2001 and 24 Sept. 2002. Each subplot was $3 \mathrm{~m}$ long with five rows spaced $23 \mathrm{~cm}$ apart.

\section{Data Collection and Analyses}

Forage samples were collected just before the beginning of grazing, which coincided with the normal turnout of cattle between late October and late November at this location. Plants were clipped to a height of $4 \mathrm{~cm}$ from three $0.5-\mathrm{m}$-long sections of an interior row in 2001 and two $0.5-\mathrm{m}$ sections in 2002. Samples were collected within a nursery by replicate from 5 to 8 Nov. 2001 and 12 to 14 Nov. 2002 and dried to constant weight at $60^{\circ} \mathrm{C}$ to measure forage biomass, then weighed and ground $(<1 \mathrm{~mm})$ for total $\mathrm{N}$ and nitrate analyses. Total $\mathrm{N}$ was determined by automated flash combustion (CHN-1000; Leco Corp., St. Joseph, MI), and nitrate in hot $\left(95^{\circ} \mathrm{C}\right)$ deionized water extracts of dried tissues was measured by a FIAstar 5010 flow injection analyzer (Foss North America, Inc., Eden Prairie, MN) equipped with a $\mathrm{Cu}$-Cd-reduction column (AN 62/83; Tecator, 1983).

Statistical analyses of the genetic backgrounds were performed using ANOVA procedures. Genetic background was considered random and data were analyzed as a mixed model using JMP software (SAS Institute, 2002). The two nurseries were analyzed separately and the check cultivars were excluded when testing effects among the two sets of experimental genetic backgrounds. Means $\pm \mathrm{SE}$ of check cultivars were calculated using observations from both nurseries within each year (SAS Institute, 2002).

\section{RESULTS AND DISCUSSION}

The ANOVA results for forage traits are summarized in Table 2. Nearly always, the genetic background $\times$ selection environment effect was not significant. Effect of selection environment on biomass of each nursery was significant at $P=0.093$ and 0.068 in 2001; in 2002 the effect of selection environment was not significant. Selection environment was a significant effect for total $\mathrm{N}$ but not nitrate levels.

\section{Forage Biomass}

In 2001, bulk populations selected from a DP management environment had mean fall forage biomass that tended to be less (Nursery $1, P=0.093$; Nursery 2, $P=$ 0.068) than the GO and base populations (Fig. 2). For both nurseries, biomass of the DP selected bulk populations averaged about 5\% less fall biomass than the bulk populations selected from the GO production system. For Nursery 2 in 2001, biomass of the base populations averaged about 3\% greater than those selected from the GO system.

The trend for less forage biomass among the populations selected from a DP system may be associated with a more pronounced prostate growth habit than among plants in the bulk populations derived from the GO

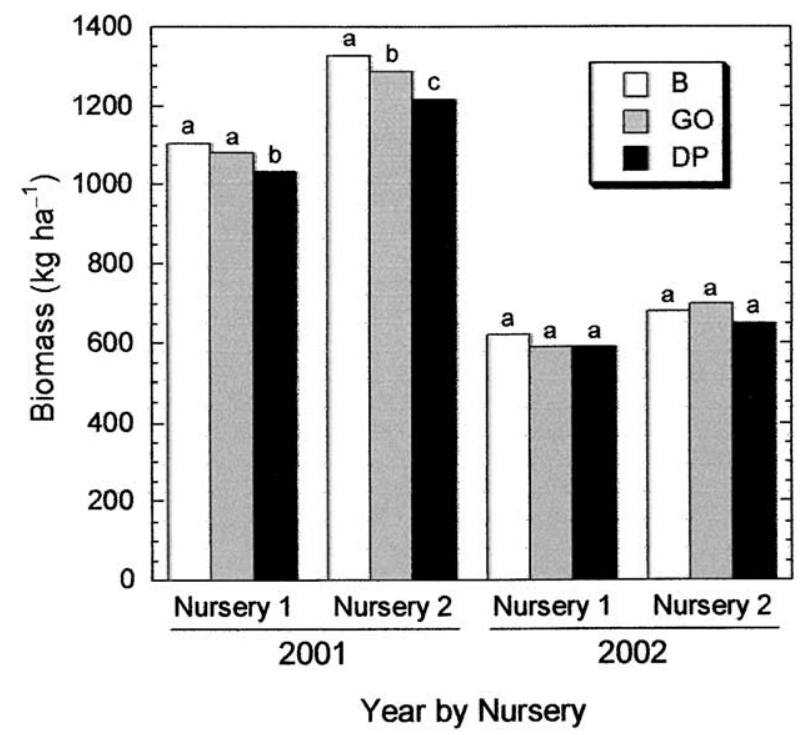

Fig. 2. Forage biomass of base (B) and selected (grain-only, GO; dual-purpose, DP) bulk subpopulations of two nurseries (Nursery 1 and Nursery 2) managed as DP wheat crops in 2001 and 2002. Biomass mean bars having the same letter within a year-by-nursery combination are not significantly different $(\alpha=0.10)$. 
Table 3. Fall forage biomass, total $\mathbf{N}$, and nitrate- $\mathbf{N}$ for three check cultivars included in both nurseries in 2001 and 2002. Values are means of 18 observations from two nurseries, three replications, and three adjacent subplots within each cultivar.

\begin{tabular}{|c|c|c|c|c|c|c|c|}
\hline \multirow[b]{2}{*}{ Cultivar } & \multirow[b]{2}{*}{ Fall growth habit } & \multicolumn{3}{|c|}{2001} & \multicolumn{3}{|c|}{2002} \\
\hline & & Biomass & Total N & Nitrate-N & Biomass & Total N & Nitrate-N \\
\hline & & $\mathrm{kg} \mathrm{ha}^{-1}$ & $\mathrm{~g} \mathrm{~kg}^{-1}$ & $\mu g^{-1}$ & $\mathbf{k g ~ h a}^{-1}$ & $\mathrm{~g} \mathrm{~kg}^{-1}$ & $\mu g g^{-1}$ \\
\hline Custer & semiprostrate & $971 \pm 83$ & $39.8 \pm 0.2$ & $1500 \pm 82$ & $624 \pm 33$ & $39.2 \pm 0.4$ & $792 \pm 84$ \\
\hline Jagger & semierect to erect & $\mathbf{1 1 7 0} \pm \mathbf{5 0}$ & $42.2 \pm 0.4$ & $1470 \pm 94$ & $694 \pm 39$ & $42.6 \pm 0.4$ & $471 \pm 42$ \\
\hline 2174 & erect & $1650 \pm 70$ & $41.6 \pm 0.4$ & $1790 \pm 116$ & $746 \pm 41$ & $41.3 \pm 0.4$ & $371 \pm 36$ \\
\hline
\end{tabular}

system (Carver and MacKown, 2001 and 2002, unpublished data). The shift toward a juvenile prostate growth habit would be consistent with a reversal of the hypothesized change from a low to a high frequency of erect phenotypes as wheat was domesticated and grazing was controlled (Waisel, 1987). As the ranking among wheat cultivars changes from prostrate to an erect juvenile growth habit, there is an increase in the amount of forage biomass that accumulates between planting in late August and clipping in late October (Carver et al., 1991). Biomass accumulated by the three check cultivars in 2001 followed this trend. Custer, a cultivar with a semiprostrate forage growth habit, accumulated $41 \%$ less biomass than 2174, a cultivar with an erect forage growth habit (Table 3). In 2001, the fall forage productivity of the experimental subpopulations was comparable with the commonly grown check cultivars because the biomass means of the subpopulations were bracketed by the range in biomass of the check cultivars (cf. Fig. 2 and Table 3). While an erect fall growth habit is normally considered more desirable for wheat forage (Ud-Din et al., 1993), selection pressures of a DP system leading to prostrate growth habit may be linked to other traits that could improve the performance of wheat intended for DP use in the southern Great Plains. Prostrate growth habit is associated with low temperature tolerance and vernalization requirement (Roberts, 1990; Limin and Fowler, 2000) and could have an impact on winter forage productivity and lengthen the days before first hollow stem when grazing of DP wheat should be terminated to assure good grain yields (Redmon et al., 1996).

In 2002, forage biomass means were unaffected by selection environment and averaged nearly $46 \%$ less than those in 2001 (Fig. 2). The growing degree-days (GDD) for the interval between planting and fall forage harvest was normal in 2001 but $14 \%$ below normal in 2002 (Table 4). This deficit, coupled with a 13\% difference of $7 \mathrm{~d}$ between the planting and harvest interval of 2001 (56 d) and 2002 (49 d), resulted in nearly 35\% fewer GDD in 2002 than 2001. This difference, coupled with a $17 \%$ less than normal total solar radiation in
2002, probably accounts for the low biomass production in 2002 rather than a limitation of rainfall (Table 4). Compared with the ranking trend of fall forage biomass in 2001, poor climatic conditions and an inadequate duration for forage development may have masked a similar trend in 2002. Among the check cultivars, biomass accumulation in 2002 appeared to be substantially less (36 to 55\%) than in 2001; however, the trend of increasing biomass with increasing erectness of the forage growth habit was still evident (Table 3). In 2002, most of Nursery 1 subpopulation biomass means were similar to Custer (lowest among the three checks), but those of Nursery 2 fell between the lower and upper biomass levels of the check cultivars (cf. Fig. 2 and Table 3).

While the forage biomass values we observed were often within the range of values reported for fall wheat pastures in central Oklahoma (Carver et al., 1991; Epplin et al., 2000; Hossain et al., 2003), these values often were less than the $1992-2000$ average of $1730 \mathrm{~kg} \mathrm{ha}^{-1}$ measured on a set of 16 pastures also located at the Marshall Wheat Pasture Center (Kaitibie et al., 2003). A $30 \%$ decrease in the amount of forage when cattle are placed on wheat in the fall translates into a $30 \%$ decrease in the economically optimum 120-d stocking rate (Kaitibie et al., 2003) and a corresponding decrease in the potential profit derived from weight gains of stockers per unit area of pasture. Consequently, it is critical that the development of wheat cultivars intended for DP use be evaluated for fall forage productivity and quality to assure rapid growth of fall-weaned calves as well as grain yield, regardless of whether they are generated from selections made in a DP or GO environment.

\section{Forage Nitrogen Traits}

Wheat forage from bulk populations selected from a DP management system consistently had overall total $\mathrm{N}$ concentrations that were slightly greater $(2.6 \%)$ than those of base and GO subpopulations (Fig. 3). Because the DP selections seem to have a more prostrate growth habit than the other selections, the proportion of the

Table 4. Cumulative rainfall, total solar radiation, and calculated growing degree-days (GDD, base temperature of $0^{\circ} \mathrm{C}$ ) for data from the Marshall Oklahoma Mesonet site located at the Marshall Wheat Pasture Center.

\begin{tabular}{|c|c|c|c|c|}
\hline \multirow[b]{3}{*}{ Climate variable } & \multicolumn{4}{|c|}{ Planting date to sample date growth period } \\
\hline & \multicolumn{2}{|c|}{10 September to 5 November } & \multicolumn{2}{|c|}{24 September to 12 November } \\
\hline & 1994-2000 & 2001 & 1994-2000 & 2002 \\
\hline $\begin{array}{l}\text { Rainfall, cm } \\
\text { Total solar radiation, } \mathbf{M J ~ m}^{-2} \\
\text { GDD, }{ }^{\circ} \mathbf{C}\end{array}$ & $\begin{array}{l}14.6 \\
822 \\
983\end{array}$ & $\begin{array}{l}10.9(-25) \dagger \\
931(13) \\
980(-0.3)\end{array}$ & $\begin{array}{l}10.7 \\
653 \\
743\end{array}$ & $\begin{array}{l}11.4(7) \\
544(-17) \\
638(-14)\end{array}$ \\
\hline
\end{tabular}

$\dagger$ Numbers in parentheses are the percentage difference from the 1994 to 2000 growth period means. 


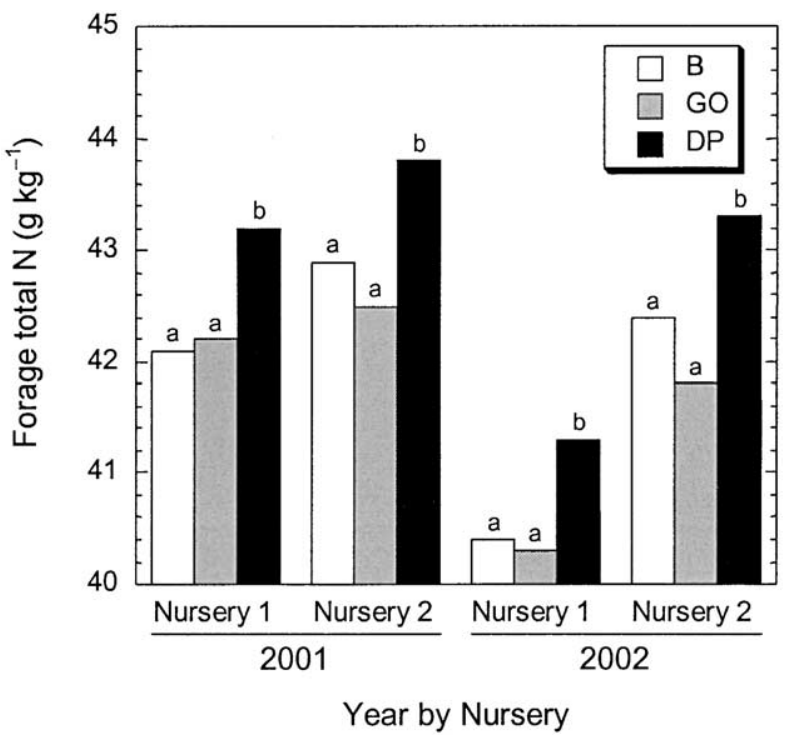

Fig. 3. Forage total $\mathbf{N}$ of base (B) and selected (grain-only, GO; dualpurpose, DP) bulk subpopulations of two nurseries (Nursery 1 and Nursery 2) managed as DP wheat crops in 2001 and 2002. Total $\mathrm{N}$ mean bars having the same letter within a year-by-nursery combination are not significantly different $(\alpha=0.05)$.

total biomass as leaf blades with high $\mathrm{N}$ concentration were probably greater than the other subpopulations. To confirm this, additional research comparing biomass partitioning and $\mathrm{N}$ concentrations between leaf blades and sheaths of fall wheat forage is needed. Among the bulk populations, total $\mathrm{N}$ concentrations ranged from 40.9 to $44.3 \mathrm{~g} \mathrm{~kg}^{-1}$ dry weight in 2001 and from 39.5 to $45.4 \mathrm{~g} \mathrm{~kg}^{-1}$ dry weight in 2002 (data not shown). These total $\mathrm{N}$ concentrations were comparable with those of the check cultivars (Table 3 ). The genetic background $\times$ selection environment interaction effect for total $\mathrm{N}$ was not significant $(P>0.05)$ except for Nursery 2 in 2001 (Table 2). Some of the genetic backgrounds of Nursery 2 in 2001 had forage total $\mathrm{N}$ concentrations that were similar among the three selection environments (Sets 1, 3 , and 12 ), while in others total $\mathrm{N}$ of the DP subpopulation was slightly greater than that of the GO selection but not the base subpopulation (Sets 5,7 , and 10) or greater than only the GO selection (Sets 4, 6, 9, and 11) (data not shown). In all cases, however, the level of total $\mathrm{N}$ (protein equivalent $>200 \mathrm{~g} \mathrm{~kg}^{-1}$ ) is more than adequate to support high rates of weight gain (up to $1.36 \mathrm{~kg} \mathrm{~d}^{-1}$ for 135 - to $225-\mathrm{kg}$ steers) for stocker calves (Torell et al., 1999), so the slight difference in total $\mathrm{N}$ created by selection system should not affect stocker performance. Unfortunately, the energy content and low dry matter (high water content) of wheat limit average daily gains to $<1.0 \mathrm{~kg} \mathrm{~d}^{-1}$ when supplement energy is not provided (e.g., Mader et al., 1983; Phillips et al., 1995, 2001; Pinchack et al., 1996).

Selection environment of the bulk populations did not affect forage nitrate concentrations, but differences among genetic backgrounds were significant (Fig. 4). Overall, mean nitrate levels of fall forage from 2001 (2020 $\mu \mathrm{g} \mathrm{NO}_{3}^{-}-\mathrm{N} \mathrm{g} \mathrm{g}^{-1}$ dry wt.) exceeded the levels in 2002 by about threefold (661 $\mu \mathrm{g} \mathrm{NO}_{3}^{-}-\mathrm{N} \mathrm{g}^{-1}$ dry wt.).

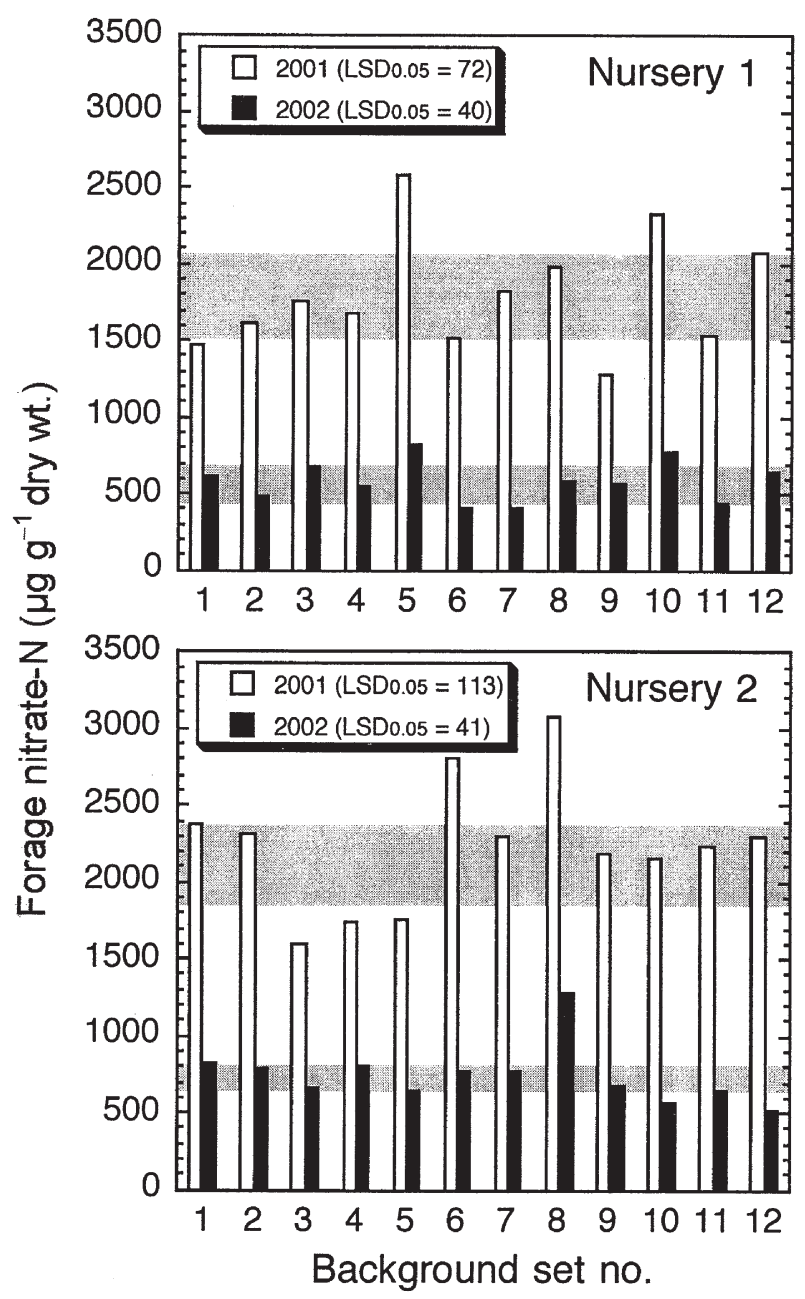

Fig. 4. Mean forage nitrate concentrations of genetic background entries in two nurseries (Nursery 1 and Nursery 2; 12 unique backgrounds in each nursery) managed as dual-purpose (DP) wheat crops in 2001 and 2002. Means are averages across the base (B) and selected (grain-only, GO; DP) bulk subpopulations. Each horizontal gray bar within a nursery marks the yearly 25 to $75 \%$ quartiles.

Similarly, the average forage nitrate levels of the check cultivars in 2001 exceeded the levels in 2002 by about threefold (Table 3). In both 2001 and 2002, a few of the same genetic backgrounds within a nursery had nitrate concentrations that ranked $\geq 75 \%$ quartile (Nursery 1 , Sets 5 and 10; Nursery 2, Sets 1 and 8). At the lower range of nitrate levels, other genetic backgrounds had concentrations that ranked consistently $\leq 25 \%$ quartile (Nursery 1 , Set 6 ; Nursery 2, Set 5 ). In 2001 , at least $50 \%$ of the 24 genetic background sets had $\mathrm{NO}_{3}^{-}-\mathrm{N}$ levels exceeding the check $2174\left(1790 \pm 120 \mu \mathrm{g} \mathrm{NO}_{3}^{-}-\mathrm{N} \mathrm{g}^{-1}\right.$ dry wt.; highest level among the check cultivars), while only one (Fig. 3; Nursery 1, Set 9) was less than Custer, the lowest check cultivar. In 2002, nearly all sets had $\mathrm{NO}_{3}^{-}-\mathrm{N}$ levels that fell within the range of $\mathrm{NO}_{3}^{-}-\mathrm{N}$ levels of the check cultivars, except for Set 9 in Nursery $2\left(1280 \mu \mathrm{g} \mathrm{NO}_{3}^{-}-\mathrm{N} \mathrm{g}^{-1}\right.$ dry wt.), which exceeded the highest check $\mathrm{NO}_{3}^{-}-\mathrm{N}$ level by $62 \%$ (cf. Fig. 3 and Table 3 ). Because all of the entries in 2001 had nitrate concentrations $>1125 \mu \mathrm{g} \mathrm{NO}_{3}^{-}-\mathrm{N} \mathrm{g}^{-1}$ dry weight ( $>5000 \mu \mathrm{g} \mathrm{NO}_{3} \mathrm{~g}^{-1}$ dry wt.) that is considered 
a threshold for risk to stockers (Strickland et al., 1995; Undersander et al., 1999), changes in N fertilizer management and development of wheat cultivars intended for DP use that have decreased nitrate concentrations would seem prudent.

In terms of fall forage biomass accumulation and concentrations of total $\mathrm{N}$ and nitrate, we found no clear advantage to choosing either the natural selection environment of the DP or the traditional GO production systems for generating bulk populations from which to derive new wheat cultivars. Even though there was a trend toward decreased fall forage biomass (and a more pronounced prostrate growth habit) when bulk populations of a range of wheat genetic backgrounds were exposed to natural selection effects of a DP production system, this strategy should not be ignored entirely. Initial fall forage biomass represents only one component of a DP wheat breeding program; other critical components include vegetative regrowth and grazing tolerance, grazing period duration and timing of firsthollow-stem stage, and grain yield after grazing, which may benefit from exploiting a DP selection environment for development of cultivars intended for this purpose (Khalil et al., 2002). More focus on the concentration of nitrate in fall forage seems warranted, considering the apparent diversity among wheat genetic backgrounds that could be used to decrease nitrate risks to young ruminants that likely are unadapted to abundant levels of forage nitrate. Finally, regardless of the production system used to develop DP wheat cultivars, productivity and quality traits of both forage and grain components need to be addressed simultaneously. For the sets of genetic backgrounds used in this study, grain yields and additional agronomic traits of plants at anthesis and maturity (unpublished data, 2002 and 2003) are forthcoming.

\section{ACKNOWLEDGMENTS}

Assistance with collection, processing, and analyses of forage samples was provided by Jeff Weik and Kory Bollinger of the USDA-ARS Grazinglands Research Laboratory. Generation of crosses and development of bulk subpopulations was made possible by personnel of Oklahoma State University including Wayne Whitmore, Dr. Gerald Horn, and Dr. Eugene Krenzer.

\section{REFERENCES}

Atkins, I.M., O.G. Merkle, and P.E. Pawlisch. 1969. Visual estimates and clipping plot size for evaluating the forage potential of small grain varieties. Agron. J. 61:88-91.

Carver, B.F., E.G. Krenzer, Jr., and W.E. Whitmore. 1991. Seasonal forage production and regrowth of hard and soft red winter wheat. Agron. J. 83:533-537.

Carver, B.F., I. Khalil, E.G. Krenzer, Jr., and C.T. MacKown. 2001. Breeding wheat for a dual purpose management system. Euphytica 119:231-234.

Epplin, F.M., and T.F. Peeper. 1998. Influence of planting date and environment on Oklahoma wheat grain yield trend from 1963 to 1995. Can. J. Plant Sci. 78:71-77.

Epplin, F.M., I. Hossain, and E.G. Krenzer, Jr. 2000. Winter wheat fall-winter forage yield and grain yield response to planting date in a dual-purpose system. Agric. Syst. 63:161-173.

Hammon, R.W., C.H. Pearson, and F.B. Peairs. 1996. Winter wheat planting date effect on Russian wheat aphid (Homoptera: Aphididae) and a plant virus complex. J. Kansas Entomol. Soc. 69:302-309.

Hossain, I., F.M. Epplin, and E.G. Krenzer, Jr. 2003. Planting date influence on dual-purpose winter wheat forage yield, grain yield, and test weight. Agron. J. 95:1179-1188.

Hossain, I., F.M. Epplin, G.W. Horn, and E.G. Krenzer, Jr. 2004. Wheat production practices used by Oklahoma grain and livestock producers [Online]. Oklahoma Agric. Exp. Stn. Publ. B-818. Available at http://osuextra.okstate.edu/pdfs/B-818.pdf) (verified 6 July 2004). Oklahoma State Univ., Stillwater.

Hunger, R.M., L.L. Singleton, E.G. Krenzer, R. Sidwell, and M.E. Payton. 2002. Effect of planting date, tillage and burning of residue on eyespot of winter wheat. Phytopathology 92:S38.

Kaitibie, S., F.M. Epplin, B.W. Brorsen, G.W. Horn, E.G. Krenzer, Jr., and S.I. Paisley. 2003. Optimal stocking density for dual-purpose winter wheat production. J. Agric. Appl. Econ. 35:29-38.

Khalil, I.H., B.F. Carver, E.G. Krenzer, C.T. MacKown, and G.W. Horn. 2002. Genetic trends in winter wheat yield and test weight under dual-purpose and grain-only management systems. Crop Sci. 42:710-715.

Krenzer, G., Jr. 1994. Wheat for pasture. Oklahoma Coop. Ext. Serv. and Oklahoma Agric. Exp. Stn. Publ. F-2586. Oklahoma State Univ., Stillwater.

Krenzer, E.G., Jr., J.D. Thompson, and B.F. Carver. 1992. Partitioning of genotype $\times$ environment interactions of winter wheat forage yield. Crop Sci. 32:1143-1147.

Limin, A.E., and D.B. Fowler. 2000. Morphological and cytological characters associated with low-temperature tolerance in wheat (Triticum aestivum L. em Thell.). Can. J. Plant Sci. 80:687-692.

Mader, T.L., G.W. Horn, W.A. Phillips, and R.W. McNew. 1983. Low quality roughages for steers grazing wheat pasture. I. Effect on weight gains and bloat. J. Anim. Sci. 56:1021-1028.

MacKown, C.T., and J.C. Weik. 2004. Comparison of laboratory and quick-test methods for forage nitrate. Crop Sci. 44:218-226.

Phillips, W.A., M.A. Brown, A.H. Brown, Jr., and S.W. Coleman. 2001. Genotype $\times$ environment interactions for postweaning performance in crossbred calves grazing winter wheat pasture or dormant native prairie. J. Anim. Sci. 79:1370-1377.

Phillips, W.A., S.P. Hart, H.A. Glimp, and D.L. VonTunglen. 1995. Supplementation to compensate for differing stocking rates for steers grazing wheat pasture. J. Prod. Agric. 8:84-88.

Piccinni, G., J.M. Shriver, and C.M. Rush. 2001. Relationship among seed size, planting date, and common root rot in hard red winter wheat. Plant Dis. 85:973-976.

Pinchack, W.E., W.D. Worall, S.P. Caldwell, L.J. Hunt, N.J. Worall, and M. Conoly. 1996. Interrelationships of forage and steer growth dynamics on wheat pasture. J. Range Manage. 49:126-130.

Raun, W.R., and R.L. Westerman. 1991. Nitrate-N and phosphate-P concentration in winter wheat at varying growth stages. J. Plant Nutr. 14:267-281.

Redmon, L.A., G.W. Horn, E.G. Krenzer, Jr., and D.J. Bernardo. 1995. A review of livestock grazing and wheat grain yield: Boom or bust? Agron. J. 87:137-147.

Redmon, L.A., E.G. Krenzer, Jr., D.J. Bernardo, and G.W. Horn. 1996. Effect of wheat morphological state at grazing termination on economic return. Agron. J. 88:94-97.

Roberts, D.W.A. 1990. Identification of loci on chromosome 5A of wheat involved in control of cold hardiness, vernalization, leaf length, rosette growth habit, and height of hardened plants. Genome 33:247-259.

Royer, T.A., K.L. Giles, and N.C. Elliott. 1997. Insect and mites on small grains [Online]. Oklahoma Coop. Ext. Serv. and Oklahoma Agric. Exp. Stn. F-7176. Available at http://osuextra.okstate.edu/ pdfs/F-7176web.pdf) (verified 6 July 2004). Oklahoma State Univ., Stillwater.

SAS Institute. 2002. JMP statistics and graphics guide. v. 5.0. SAS Inst., Cary, NC.

Strickland, G., G. Selk, E. Allen, and T. Thedford. 1995. Nitrate toxicity in Livestock. Oklahoma Coop. Ext. Serv. and Oklahoma Agric. Exp. Stn. F-2903. Oklahoma State Univ., Stillwater.

Tecator. 1983. Application note (AN62/83): Determination of the sum of nitrate and nitrite in water by flow injection analysis. Foss North America Technology, Eden Prairie, MN. 
Torell, R., W. Riggs, B. Bruce, and B. Kvasnicka. 1999. How good is wheat pasture for winter grazing lightweight calves [Online]? Available at http://www.ag.unr.edu/AB/Extension/Cattleman/Cattleman 99/09.htm (verified 6 July 2004). Univ. Nevada Coop. Ext., Reno.

Ud-Din, N., B.F. Carver, and E.G. Krenzer, Jr. 1993. Visual selection for forage yield in winter wheat. Crop Sci. 33:41-45.

Undersander, D., D. Combs, T. Howard, R. Shaver, M. Siemens, and D. Thomas. 1999. Nitrate poisoning in cattle, sheep, and goats
[Online]. Available at http://www.uwex.edu/ces/forage/pubs/nitrate. htm (verified 6 July 2004). Univ. of Wisconsin Coop. Ext., Madison. Waisel, Y. 1987. Evolution of erect growth forms in domesticated wheats: Possible effects of grazing. Oecologia 73:630-632.

Zhang, H., G.V. Johnson, W.R. Raun, N.T. Basta, and J.A. Hattey. 1998. OSU soil test interpretations [Online]. Oklahoma Coop. Ext. Serv. and Oklahoma Agric. Exp. Stn. F-2225. (Available at http:// osuextra.okstate.edu/pdfs/F-2225web.pdf) (verified 6 July 2004). Oklahoma State Univ., Stillwater. 